\title{
A Case of Lyme Disease With Cardiac Involvement in The Netherlands*
}

Since 1975, Lyme disease has become a well-known clinical entity in the U.S.A. In 1983 the spirochetal origin of this disease became evident (1). The skin lesion, one of its symptoms, was classified as erythema chronicum migrans. This lesion has been well known in Europe since the early 1900 s but seems more prevalent in the U.S.A. In recent years very few cases with the full clinical picture of Lyme disease have been described in Europe $(2,3)$. The spirochetal origin has been established in some of them. As far as we know, we observed the first case of Lyme disease in The Netherlands; we were able to confirm the spirochetal origin by serological findings.

A 22-year-old man was admitted to our coronary care unit on October 14th, 1983, with a third-degree atrio-ventricular block. Six weeks previously he had noticed an oval red skin lesion over his right thigh about $15 \mathrm{~cm}$ in diameter with central clearing. This lesion appeared several days after a tick bite in the same place. It disappeared after three weeks and was followed by slight swelling and pain in the right hip. He felt feverish, had chills during the night and noted an enlarged lymph node in the right groin. These symptoms lasted for two weeks and were followed by transient dizziness and a period of complete loss of consciousness. He was admitted to hospital and we diagnosed a fluctuating A-V block. Periods of first, second and third-degree A-V block were seen. In addition, the electrocardiogram showed $\mathrm{T}$-wave inversions in the precordial leads. This complex of symptoms, which developed after a tick bite, seemed compatible with Lyme disease. We subsequently treated our patient with penicillin and he recovered completely. Since then he has had no complaints.

Determinations for serum antibody against the Lyme spirochete using the enzyme linked immunosorbent assay confirmed the diagnosis of Lyme disease. IgM antibody titers against the Ixodes damnini spirochete were $400 \mathrm{U}$

\footnotetext{
* See pages 331-337, Wilske et. al.
}

and IgG antibody titers $800 \mathrm{U}$ on October 16 th. These titers indicate a recent infection, as healthy control subjects have IgM and IgG responses of $200 \mathrm{U}$ in this assay.

These findings give supportive evidence that a related or identical organism is the causative agent of Lyme disease in The Netherlands. Because the same conclusions were recently drawn in the presentation of cases from France, Germany and Sweden $(2,4,5)$, it seems reasonable to state that there is every chance that this may concern the whole of Europe.

\section{J. Houwerzyl, J. J. Root, J. A. A. Hoogkamp-Korstanje}

\section{Acknowledgements}

We would like to thank Prof. Dr. A. C. Steere, Yale University, New Haven, U.S.A. for performing the serological tests.

\section{Literature}

1. Steere, A. C., Grodzicki, M. S., Kornblatt, A. N.: The spirochetal etiology of Lyme disease. N. Engl. J. Med. 308 (1983) 733-740.

2. Ackermann, R., Runne, U., Kleuk, W., Dienst, C.: Erythema chronicum migrans mit Arthritis. Dtsch. Med. Wochenschr. 105 (1980) 1779-1781.

3. Kahan, A., Dougados, M., Vannier, A., Amor, B.: Spirochaetal, etiology for Lyme disease. Lancet II (1983) 174.

4. Ackermann., R., Kabatzki, J., Boisten, H. P.: Spirochäten Ätiologie der Erythema-chronicum-migrans Krankheit. Dtsch. Med. Wochenschr. 109 (1984) 92-97.

5. Ryberg, B., Nilsson, B., Burgdorfer, W., Barbour, A. G.: Antibodies to Lyme disease spirochete in European lymphocytic meningoradiculitis. Lancet II (1983) 519

J. Houwerzyl, J. J. Root, Department of Internal Medicine and Cardiology, Bonifatius Hospital, Medical Centre Leeuwarden, NL-8917 CR Leeuwarden;

Jacomina A. A. Hoogkamp-Korstanje, Laboratory of Public Health, Jelsumerstraat 6, NL-8917 EN Leeuwarden.

\section{Information}

\section{New WHO Publications}

E. M. Backett, A. M. Davies, A. Petros-Barvazian:

The Risk Approach in Health Care

Public Health Paper No. 76

World Health Organization Geneva, 1984

113 pages.

B. M. Kleczkowski, M. I. Roemer, A. van der Werff:

National Health Systems and their Reorientation Towards

Health for All

Public Health Paper No. 77

World Health Organization Geneva, 1984

120 pages.
C. E. Taylor:

The Uses of Health Systems Research

Public Health Paper No. 78

World Health Organization Geneva, 1984

50 pages.

World Health Statisties Quarterly

Vol. 37, No. 1, 1984

World Health Organization

128 Seiten. (Enthält keine infektiologischen Probleme). 